\title{
MCDM TECHNIQUE TO EVALUATING MOBILE BANKING ADOPTION IN THE TOGOLESE BANKING INDUSTRY BASED ON THE PERCEIVED VALUE: PERCEIVED BENEFIT AND PERCEIVED SACRIFICE FACTORS
}

\author{
Gbongli Komlan $^{1 *}$, Dumor Koffi ${ }^{2}$ and Kissi Mireku Kingsford ${ }^{3}$ \\ ${ }^{1 *, 2}$ School of Management and Economics, \\ ${ }^{3}$ School of Information and Software Engineering, \\ ${ }^{1 *, 2,3}$ University of Electronic Science and Technology of China (UESTC)
}

\begin{abstract}
Development of new technological innovations in networks, platforms, and financial institutions has empowered m-banking service providers to target their business strategies plan with confidence.

Nevertheless, lots of service innovations have failed to generate revenue due to lagging adoption issues. Even though, several prior researches have focused on the factors that influence the acceptance of $m$ banking, there is limited empirical study which simultaneously take the success factors (perceived benefit) and resistance factors (perceived sacrifice) that contribute to the customers adoption of $m$ - banking. Furthermore, most previous researches investigate on the overall aspects related to the adoption of mobile banking, have used multiple regression methods (structural equation modeling or technology acceptance technique) or some MCDM tools. However, these studies still have some shortcoming due to lack of delivering the enough information about these factors and their prioritizing facets. Nowadays, only those organizations which major goal is to achieve customer's expectations with maximum quality can be successful in the market environment. This research reviewed the literature, took the advice from the experts in the field of m-banking service, and constructed the structural hierarchical table of the factors that affecting perceived value on consumers' adoption of mobile banking. Via a pairwise comparisons scale, a questionnaire designated was distributed to some university students in Lomé-Togo and later used AHP (Analytic Hierarchy Process) to weigh each criteria, sub-criteria and alternative in order to rank them according to their preference. The finding revealed that financial risk is the utmost factor impacting the m-banking adoption, follow by money saved element. Both factors explain how consumers are more concerned with the financial or monetary issues and far ahead Security \& Privacy risk come to confirm that, Togolese Banking industry should guarantee the safety and personal detail issues when customers are dealing with this m-banking technology.
\end{abstract}

This research contributes to the existing literature by providing new insights to how AHP can be applied to assess consumer's preference in m-banking in a developing country. Moreover, knowledge acquire from the influential factors will enable firms to better exploit their scarce resources, by formulating management strategies based on the priorities of these factors, and consequently, satisfy consumer needs and wants at lower cost while greater efficiency should be promoted. 
International Journal of Data Mining \& Knowledge Management Process (IJDKP) Vol.6, No.3, May 2016

\section{KEYWORDS}

MCDM (Multi Criteria Decision Making); AHP (Analytic Hierarchy Process); M-Banking; Perceived Value; Perceived benefit; Perceived Sacrifice; Togo

\section{INTRODUCTION}

A foremost technological revolution is leading today's world, particularly in the area of Information Technology (IT). This growth of IT is becoming a vital factor in the future development of industries and businesses around the world which makes it as global village where almost everything is being done via technology-based. Centered on the Internet Live Stats (elaboration of data by International Telecommunication Union (ITU) and United Nations Population Division) statistic, almost $40 \%$ of the world's population has an internet connection facility today. From its fixed line constraints, internet's development is increasing mobile, placing Mobile Banking in a higher market position. With all its versatile user application interfaces, mobile users can have a full access to the internet facilities now. While, ATM, Telephone and Internet Banking offer successful ways as compared to traditional banking products, M-Banking sector is the newest channel settle by retail and microfinance banks in developed and developing countries and predicted to have high effect on the market [1]. Mobilebanking is a service that includes financial transactions and payments by the use of a users' mobile phone handset which they can access at anytime and anyplace. Studies proved that the MBanking usage as a canal for banking transaction is still under premature stage, though such benefits have been provided [2]. The growth in M-B services is not revealing the same level with the boom in mobile technology, and the evolution in this technological adoption rate is still sluggish. Consequently, persuading consumers to shift their traditional Banking channel's behavior to M-B is quiet complicated as a process mostly, since there is a lack of understanding of this reality from the customers' perspective [3]. Moreover, the prospective for increasing an organization's customer base, activating the use of more volatile customer mix and improving the firm's reputation rely on the customer's satisfaction [4]. Recognizing the needs and wants of its customers and being able to satisfy them, must be the main duty of every organization susceptible to gain a competitive advantage. The application of mobile in the banking sector in Togo is not yet well pronounced as compared to other developed countries in the world; even some developing countries in Africa and the Banks should have a critical role to play in this. Allowing for the rate of Adoption in Africa particularly within the different part of Africa, SubSaharan Africa (SSA) has developed by uprising the use of the third generations ( $2 \mathrm{G}$ and $3 \mathrm{G}$ ) mobile phones to solve the pecuniary activities. East Africa essentially Kenya, Vodafone brought a great success by managing the M-PESA mobile money [5], [6]. However, the rate of adoption in Togo according to Financial Afrik is only 1\% [7] and a recent research [8] has confirmed that among the self-service technology, Mobile Banking adoption in Togo is the least used behind Online Banking and ATM.

What are some of the factors which might influence customers not to fully embrace such technology in Togo? Under this complex and fast-changing business atmosphere, bank managers are confronted with a multitude of decisions at any time. Making a decision have been a constant situation where they find themselves even if they are not willing to do so. Pearce II (1989) [9] pointed out that decision-making is unavoidable, because to obviously dodge making a decision is in itself, is decision made. To overcome these facts, those companies like Flooz (Etilasat), 
Wari, Togocell, Ecobank, operating M-Banking service in Togo have responded in most bank industry or financial company through the development of advertising service, promoting free service within some specific time of the day, working together with some network service providers for the use of smart phone in order to fulfil their financial requirements.

These programs however remained not based on deep investigation which led to its limited success. As a result, Rogers (2003) [10] gives a reason associated with the "start-up phase", which emphasizes the need to collect information and planning, appears to be missing in this deep and long process of the technology's implementation.

Furthermore, M-Banking technology will not be accepted and used, unless potential customers have the necessary knowledge and skills to apply it in their daily activities, regardless of its sophistication and advancement. The main participation of individual to take advantage of the technology plays an effective mediator for the expansion of M-Banking. There is a certainty that customer perception about the adoption of M-banking contributes a lot to the barrier of the development of M-banking. Risk Perceived and Trust are interconnected facets which have been generally attested to be the major elements of the online service mainly in the banking sectors [11], [12]. The Sacrifice factors have also been pointed out from the work of Layla (2014) [13], [14] as inhibitor of IT acceptance. Then, the more constant or fixed are perceived sacrifices; the more the perceived value of new technology tends to be higher when the perceived benefits increase.

Although a great deal of literatures has been done in order to totally understand these factors and their significance [15], [16], [17], mostly highlighted on innovation diffusion theory, the Technology Acceptance Model (TAM) as the foundation and from the perspective of accept the new technology, little have been found to shed light on the perspective of perceived value exploration of mobile banking user's adoption. More of these previous researchers explained TAM as initially proposed to get insight to the employees' behavior in the organization to accept new technology, which employees are settled not to bear any cost for using the proposed technology and under the unwilling situation basically. It is noteworthy to understand that, mobile banking users are exposed to their own expenses and under the condition of voluntary acceptance; therefore, TAM has the drawback of explaining the individual level of acceptance of Mobile Banking rather than the technology user's view.

Since assessing perceived value factors normally includes multiple criteria, it can be modeled as a Multiple Criteria Decision Making (MCDM) problem. This study applies AHP, one of the MCDM methods, to evaluate and prioritize the potential facilitators and inhibitors of mobile banking adoption in order to alert banks operating mobile on the fact. AHP is the right approach for the present study, as it combines all of the revealed factors into a model and measure quantitatively the importance of user requirements through the pairwise comparison of decision criteria [18]. Few researches have been found to use AHP or Fuzzy AHP to assess mobile banking adoption factor [19], [20].

Furthermore, financial institutions in Togo mostly evaluate the technology service on the managerial scale; thus this research seems to be the first attempt to use AHP techniques in such a developing country's mobile banking environment. The motivations of this research are: 
- To explore whether perceived benefit and sacrifice significantly influence customers' behavioral intention to use mobile banking.

- To elucidate which criteria are more influential in the decision to use M- banking.

The contribution of this research turns to be in various aspects: By enlightening users' perceived value factor through evaluating benefits and sacrifices factors from user's perspective, the results of this investigation cannot only aid mobile banking authorities improve a more user-accepted mobile banking system, but can also offer attentiveness in the best way to promote new IT systems to potential users. This study might also provide practitioners an increased understanding of customers' sacrifice perceptions which can then be used to devise sacrifice-reducing strategies i.e. risk and cost one part, and benefit building tools to motivate Mobile Banking adoption, especially in the evolving area of e-payments.

This research also contributes to the existing literature by adding value to the field of AHP application in order to evaluate m-banking consumer's preference in a developing country. Moreover, knowledge acquire from the influential factors, hopefully will enable firms to better exploit their limited resources, by formulating management strategies based on the priorities of these identified factors, and consequently, to satisfy consumer needs and wants at lower cost and with greater efficiency.

The remaining sections of the paper are organized as follows: the next section gives an overview of the related works; proposed research methodology, section 3; numerical application of the proposed method, section 4 . Results analysis and discussions are then presented in section 5, followed by conclusions and limitations in section 6 .

\section{RELATED WORKS}

Having the purpose of clarifying the different perspectives associated with perceived value by the customer, and evaluating the common point of the literature's definitions, there are two major aspects in consumer value. The first is the product-related, which differentiates it from personal or organizational values. Second, it is perceived by customers, and cannot be assessed accurately by the sellers, i.e., the only person who will be able to identify whether or not a product or service offers value is the consumer itself. In addition, that perceived [21], [22] value mostly can be seen as an outcome weighted from perceived benefits and perceived sacrifices. Purchase behavior positively depends on customer value perceptions and refers to the value that customers perceive, receive or experience by using the service [23]. Moreover, Zeithaml (1988) [24] defines customer perceived value as the consumer's overall assessment of the utility of a product grounded on perceptions of what is received and what is given. A research by Bankole et al. (2011) [25] done in Nigeria, one of the developing countries in West Africa, concluded that cultural background and values have also significantly influenced the m-banking adoption in the country.

Ever since, the literature has taken two different perspectives to conceptualize customer perceived value, either as a unidimensional or a multidimensional construct [26].

Unidimensional group defines perceived value as price perception or the tradeoff between perceived quality and sacrifice [27], [28]; [29]. They perceived values as a construct constituted by two parts, one of the benefits received (economics, social and relational) and the other part 
made of sacrifices factors (Price, time, risk, effort and convenience) by the consumer. This first approach which is the unidimensional one was criticized for its lack of explaining the complex and multifaceted nature of perceived value. For the purpose of providing the complete view of this complex concept, this drove researchers to put forward multidimensional, Sweeney and Soutar (2001) [30] settled the so-called 'PERVAL' scale centered on price/value for money, the performance/quality, emotional value, and social value four criteria and applied 3 dimensions of perceived value i.e. monetary value (price/value for money), functional value (performance/quality).

In line with the multidimensionality of perceived value group, Mattson (1991) [31] dealt and captured the cognitive, affective, and logical aspects of perceived value, Sheth et al. (1991a, 1991b) [32], [33] directed with the same view, even identified five dimensions of the concept of value (social, emotional, functional, conditional and epistemic). They explained functional value to be perceived utility of the attributes of the products and services, emotional value as the feelings, mood or the affective states caused by the experience of consumption, social value as the acceptability or utility at the level of the individual's relationships with his social environment. Epistemic value for its part is the capacity of the product or service to surprise, stir up curiosity or satisfy the desire for knowledge. Finally, conditional value is related to the situational factors such as illness or specific social situations. For the drive of this research, we empirically examine the selection mobile banking services and scrutinizes possible differences in customer perceived value associated with its adoption. These are founded in dual structured: perceived benefit and perceived sacrifice including perceived risk and perceived cost as subcriteria.

\subsection{Mobile Banking's Perceived Benefit}

Perceived benefits are defined as advantages brought by the use of mobile banking services when referring to value-based adoption model (VAM) [21]. In today's financial institution environment, M-Banking has recently driven consumer, practitioner and research attention for being considered as one of the most effective banking transaction methods due to many advantages which offline banking channels cannot proved to be utmost. Taking into consideration, the argument provided by lee (2008) [34] at a certain degree; there are two major types of perceived benefits, which encompass direct and indirect advantages. Direct advantages denote tangible benefits and immediate that consumers would appreciate by using Online Banking, therefore M-Banking. These advantages may be from a wider range of financial benefits, speed on transaction process (time saved), and better information transparency.

M- Banking automates the process by enabling transactions over websites and electronic data interchange, and definitely customers to interact with bank staff regarding transaction details has been reduced since these transactions can be obtained at a website and at the same time, more appropriate information is instantly available and transparent to users. The indirect benefit explains how M-Banking allows users to access their bank information at any time and everywhere, which benefit appears not to be easy to evaluate.

\subsection{Perceived Sacrifice}

In terms of perceived sacrifice, customers usually may be victims to suffer from both monetary and non-monetary costs in order to obtain a service or product. Sacrifice factors refers to the 
expectations of what the customer has to give up or forego, in profit for the service. These may include costs and risks associated with a particular service, though consumers may not always want low prices, but constantly want the service to be worth the money spend. In some cases, non-monetary sacrifices - like time, effort, energy expended might be even more vital than monetary sacrifices for some consumers. Many studies from the sacrifice component perspective to conceptualize service value, include the work of Lam et al.[35], Lin et al. (2005) [36], and Wang et al. (2004) [37], which further propose that this factor should appear in the present conceptualization of service value.

In contrast to some of the customers, Cost is one of the major factors that customers might be taken into consideration in their daily decisions to use m-banking. Therefore, lower costs are expected to draw more consumers as compared to higher costs. Luarn and Lin (2005) [15] stipulated that perceived cost is the extent to which "a person believes that using M-Banking will cost money" and has significant effect on intention to use m-banking. Further major research from Luo, Zhang and Shim (2010) [38] showed that customers perceive the cost of the technology to be very high, and this attitude may be due to the lack of awareness about mbanking. By all means, using mobile banking, users must incur the cost including, banking service fees, communication fees and others fees. The cost of gaining access to mobile and wireless internet has habitually been higher than that of accessing wire-based internet

In terms of risk perceived, it is mostly thought as felling uncertainty concerning possible negative consequences of using a product or service. It has formally been defined as "a combination of uncertainty add to the gravity of outcome involved" (Bauer, 1967) [39], and "the expectation of losses associated with procurement and acts as an inhibitor to purchase behavior" [40]. Perceived risk concept has been applied mostly to elucidate consumers' behavior since 1960s. From the traditional end-user decision making [41], several of previous studies have been done to shed light on the risk aspect. Featherman and Pavlou (2003) [11] explained perceived risk as the possible loss when chasing a desired result. Peter and Ryan (1976) [40] proposed the definition of perceived risk as a kind of subjective expected loss. According to Cunningham (1967) [42], perceived risk consisted of the size of the possible loss if the results of the act were not favorable and the individual's subjective feelings of certainty that the outcome will not be promising. Most of scholars appealed for the multi-dimensional hypothesis of perceived risk and conclude on six components: financial, performance, social, physical, privacy, and time-loss [43], [44] and [45]. However, the dimensions of perceived risk may vary according to the product (or service) class [11]. Therefore m-banking is exempted from any threat to human life and then considering physical risk in this research will not be so relevant. Based on the above conception, we proposed a new perceptive of perceived risk in m-banking as the subjectively determined probability of loss by M-B user in expecting a particular online transaction.

Little empirical research however exists on the effects of perceived cost and perceived risk facet of sacrifice factor on customer mobile banking service's adoption in Togo. Thus, this study intends to look at these two neglected dimensions by restructuring the different sub-criteria in cost and risk perceived. 
International Journal of Data Mining \& Knowledge Management Process (IJDKP) Vol.6, No.3, May 2016

\section{RESEARCH METHODOLOGY}

This section refers to the proposed method that this paper used to evaluate the different indicator of m-banking adoption. The following sequences clarify the main components of the approach.

\subsection{Application of AHP to Analyze Priorities}

The Analytic Hierarchy Process (AHP) is a Multi Criteria Decision Making (MCDM) method introduced by Saaty (1977) [46]. AHP provides a solution for decision makers to create the hierarchical structure of a complex problem, using the relationships of the overall priority, objectives, criteria, and alternatives. It is a technique for solving problems with complex multiple criteria which is called hierarchical analysis method [47], mostly applied to help decision-makers for prioritizing alternatives in order to determine the optimal alternative using pair-wise comparison judgments [48]; [49]. AHP technique sub-divides a complex decision making problem into easily understandable hierarchy elements, and makes decisions based on the elements which convert qualitative factors into quantitative variable. AHP method has two characteristics, firstly to divide the issue into category based on the property of the subject and the final objectives, secondly to construct a hierarchical structure model by which the causalities among the factors, sub-factors and alternatives are made [50]. Allowing decision makers or the participants made up of multiple experts having the task to weigh the criteria, eliminate the bias decision making and provides impartiality [51]. The selection process of AHP is based on the different steps as follow [50]; [52]:

Step 1: Definition of the problem and deciding on the criteria. Factors and related sub factors should be correlated [53].

Step 2: Structure the problem into hierarchy considering the objective of the decision, while the data are collected from experts or decision-makers corresponding to the structure

Step 3: Construction of set containing all judgments in a square comparison matrix which set of elements is compared with itself (size $n \times n$ ) by using the fundamental scale of pairwise comparison revealed in assign the reciprocal value in the corresponding position in the matrix. Using $n(n-1) / 2$ comparisons help to establish the full set of pair-wise judgments for $n$ criteria [53]

Step 4: The principal eigenvalue and the associated normalized right eigenvector of the comparison matrix provide the relative importance of the various criteria being compared. The elements corresponding to the normalized eigenvector become weights with respect to the criteria or sub-criteria and ratings with respect to the alternatives.

Step 5: Calculation of the Consistency Index (CI) and Consistency Ratio (CR) of the matrix of order $n$.

Taking the pairwise comparison through the matrix of judgements eq. (2), the basic assumption can be explained as follow: 
International Journal of Data Mining \& Knowledge Management Process (IJDKP) Vol.6, No.3, May 2016

$$
a_{i j}=\frac{1}{a_{i j}}
$$

Table1: The Fundamental Scale for Pair-wise Comparisons

Note: Element $\mathrm{a} \& \mathrm{~b}$ are any two of the criteria.

\begin{tabular}{|c|c|c|}
\hline $\begin{array}{l}\text { Intensity of the } \\
\text { Importance }\end{array}$ & Definition & Explanation \\
\hline 1 & Equal importance & Element $\mathrm{a}$ and $\mathrm{b}$ contribute equally to the objective \\
\hline 3 & $\begin{array}{l}\text { Moderate importance of one } \\
\text { over another }\end{array}$ & Slightly favor element $a$ over $b$ \\
\hline 5 & Essential importance & Strongly favor element a over $\mathrm{b}$ \\
\hline 7 & Demonstrated importance & Element $\mathrm{a}$ is favored very strongly over $\mathrm{b}$ \\
\hline 9 & Absolute importance & $\begin{array}{l}\text { The evidence favoring element a over } \mathrm{b} \text { is of the } \\
\text { highest possible order of importance }\end{array}$ \\
\hline $2,4,6,8$ & $\begin{array}{l}\text { Intermediate values between } \\
\text { the two adjacent judgments }\end{array}$ & $\begin{array}{l}\text { When compromise is needed. For example, } 4 \text { can be } \\
\text { used for the intermediate value between } 3 \& 5\end{array}$ \\
\hline $\begin{array}{l}1 / 3,1 / 4,1 / 5 \\
1 / 6,1 / 7,1 / 8,1 / 9\end{array}$ & \multicolumn{2}{|c|}{$\begin{array}{l}\text { These values represent the opposite of the reciprocal whole numbers. For example, } \\
\text { if "9" means that } \mathrm{x} \text { is much more important than } \mathrm{y}, 1 / 9 \text { means that } \mathrm{x} \text { is much less } \\
\text { important than } \mathrm{y}\end{array}$} \\
\hline
\end{tabular}

For instance, the judgement 7 for the pair $(\mathrm{X}, \mathrm{Y})$ indicates that the value in the pair $(\mathrm{Y}, \mathrm{X})$ is $1 / 7$

$$
A w=\left[\begin{array}{cccc}
1 & w_{1} / w_{2} & \cdot & w_{1} / w_{n} \\
w_{2} / w_{1} & 1 & \cdot & w_{2} / w_{n} \\
\cdot & \cdot & \cdot & \cdot \\
w_{n} / w_{1} & w_{n} / w_{2} & \cdot & 1
\end{array}\right]\left[\begin{array}{c}
w_{1} \\
\cdot \\
\cdot \\
w_{n}
\end{array}\right]=n w
$$

Centered on these judgements, the next steps of the process apply them to determine the vector of local priorities of the factors in a sub-problem with respect to their parent. According to Saaty's theory, every element in the matrix is an estimation of the ratios of the corresponding local weights [18]

$$
a_{i j}=w_{i} / w_{j} \quad i, j=1,2, \ldots . n
$$

In the same line, there is an expectation that the decision maker should be consistent in the judgement making process: In the case where the factor $X$ is preferred over $Y$ by 3 times and the factor $\mathrm{Y}$ also is preferred over $\mathrm{Z}$ by 5 times. Then the factor $\mathrm{X}$ is preferred over $\mathrm{Z}$ by $3 \times 5=$ 15 times. Meaning, for every $\mathrm{i}, \mathrm{j}, \mathrm{k}$ belong to the matrix satisfy the equation

$$
\begin{aligned}
& a_{i j} a_{j i}=a_{i k} \\
& A w=\lambda_{\max } w
\end{aligned}
$$

The computation of the consistency index (CI) adopts the value

$$
\mathrm{CI}=(\lambda \max -\mathrm{n}) /(\mathrm{n}-1)
$$


It is compared with the average RI obtained from associated random matrices of order $\mathrm{n}$ to measure the error due to inconsistency (Saaty, 1990).

The computation of the consistency ratio (CR) adopts the value:

$$
\mathrm{CR}=\mathrm{CI} / \mathrm{RI}
$$

A consistency ratio (CR) value of $10 \%$ or less is considered acceptable; otherwise the pairwise comparisons should be revised. After calculation is made in the way presented above, the relative weights of decision-making are summed to prioritize alternatives to be evaluated. The general importance is expressed as $C[1, k]=\prod_{\mathrm{i}=1}^{\mathrm{n}} \mathrm{Bi} \times C[1, k]$ means the general weight of $\mathrm{k}^{\text {th }}$ hierarchy element in the $1^{\text {st }}$ hierarchy, and $\mathrm{Bi}$ means $\mathrm{n}_{\mathrm{i}-1} \times \mathrm{a}_{\mathrm{i}}$ matrix that contains the row forming the estimated w vector. Experts or participants are asked to compare the criteria on a pairwise basis to determine their relative importance

Table2: Average RI Value

\begin{tabular}{|l|l|l|l|l|l|l|l|l|l|l|}
\hline $\mathrm{n}$ & 1 & 2 & 3 & 4 & 5 & 6 & 7 & 8 & 9 & 10 \\
\hline (Random Index) RI & 0.00 & 0.00 & 0.58 & 0.90 & 1.12 & 1.24 & 1.32 & 1.41 & 1.45 & 1.49 \\
\hline
\end{tabular}

(Remark: $n$ is the number of factors)

Step 6: maximized eigenvalue, CI and CR are confirmed to help getting the weights of each criteria [54]. In case of the evaluation of judgment of a group of participants and not a single decision maker, there is a need for extra step to complete the requirement: Aggregation of the individual priorities into an overall result. Mostly, a set of three main properties is considered when selecting the appropriate aggregation function, while applying AHP in group decision making.

*Unanimity: if $\mathrm{X}$ is prioritized over $\mathrm{Y}$ then the overall priority of $\mathrm{X}$ must be higher than the priority of $\mathrm{Y}$.

*Homogeneity: if all individuals judge a ratio t times as large as another ratio, as a result, the judgment's aggregation must also be t times as large.

*Reciprocity: it is pointed out that the synthesized value of the reciprocal of the individual judgments should be the reciprocal of the synthesized value of the original judgment. Evidence of this fact, have been demonstrated by Acze'l and Saaty (1983) [55] that the arithmetic mean and the geometric mean satisfy the first two properties when aggregating individual judgements but only the geometric mean should be chosen if the objective is to confirm that reciprocity is also satisfied.

Briefly, for this present study, AHP method is used to determine the weight of the selection criteria and sub-criteria in order to rank them according to their priorities, and finally rank the alternative associated with each criteria. Two criteria i.e. Perceived Benefit and Perceived Sacrifice connected with its Subcriteria1 (Perceived Risk and Perceived Cost) were identified. 


\section{The NUMERICAL APPlication OF THE PROPOSED MeTHOD}

\subsection{Sampling and Data Collection}

This study used a case study methodology to obtain an in-depth knowledge of m-banking adoption criteria. Indeed, Yin (1994) [56] made the use of case study methodology so popular. A case study therefore might be an appropriate approach in order to explore, the phenomenon in its own natural situation. Under this circumstance, the whole objectives and meanings can be followed as to allow the researcher study the entire supply chains [57]. In line with the existing literature, Oke and Gopalakrishnan (2009) [58] proved to the true that a case study is also significant (where existing knowledge become constrained) as it provides in-depth contextual information which may result in a superior level of understanding. Some few university students in Lomé-Togo have been selected for this research as we believed that they are quiet familiar with the mobile banking domain and might offer a wide spectrum experience in the field, and the potential users of M-Banking since many of them are using smart-phone. Furthermore, some of them have experienced the usage of mobile to pay their school registration fees at the University. The data was collected through self-administered questionnaire to these highly educated participants for the month of February 2016. Since then, the element of analysis is the decisions made and not who made the decisions, using a representative sample in AHP it is not so important. Considering this fact, Duke and Aulla-Hyde (2002) [59] stipulated that a small sample have been applied in various AHP research contrary to conventional consumer surveys and statistical analyses where a large number of samples it is recommended to be used. Shrestha, Alavalapati, and Kalmbacher (2004) [60] argued that AHP is mostly used to study participant who have knowledge about the topic under investigation and large number of sample is not needed, unless the purpose is to generalize and to capture greater heterogeneity, then a large sample is suggested. Dias and Ioannou (1996) [61] also showed that AHP is not a statistics-based methodology, therefore the study may not necessary include a significant statistical sample size. Based on the literature review and Expert view on the subject matter, the criteria and sub-criteria influencing the consumer's perceived value to embrace m-banking was determined. We then established the questionnaire from the hierarchy structure illustrated in (Fig1) to enable pairwise comparisons between all the criteria, sub-criteria, and alternative in each level in the hierarchy using Saaty's 1-9 scale taking into consideration the main goal of the study. Additional, use this survey questionnaire results as input for the AHP, which scale is non probability rather judgmental sampling.

\subsection{Hierarchical Structure and Results}

In accordance with the literature review and the expert views, we found 2 criteria in level 1 , and 2 sub-criteria in level 2, and 13 alternatives factors that may highly contributed to the perceived value in mobile banking adoption process. These facts finally help to establish the decision hierarchy structure (Fig1) based on the overall objectives: Evaluation of perceived value on mbanking adoption process 


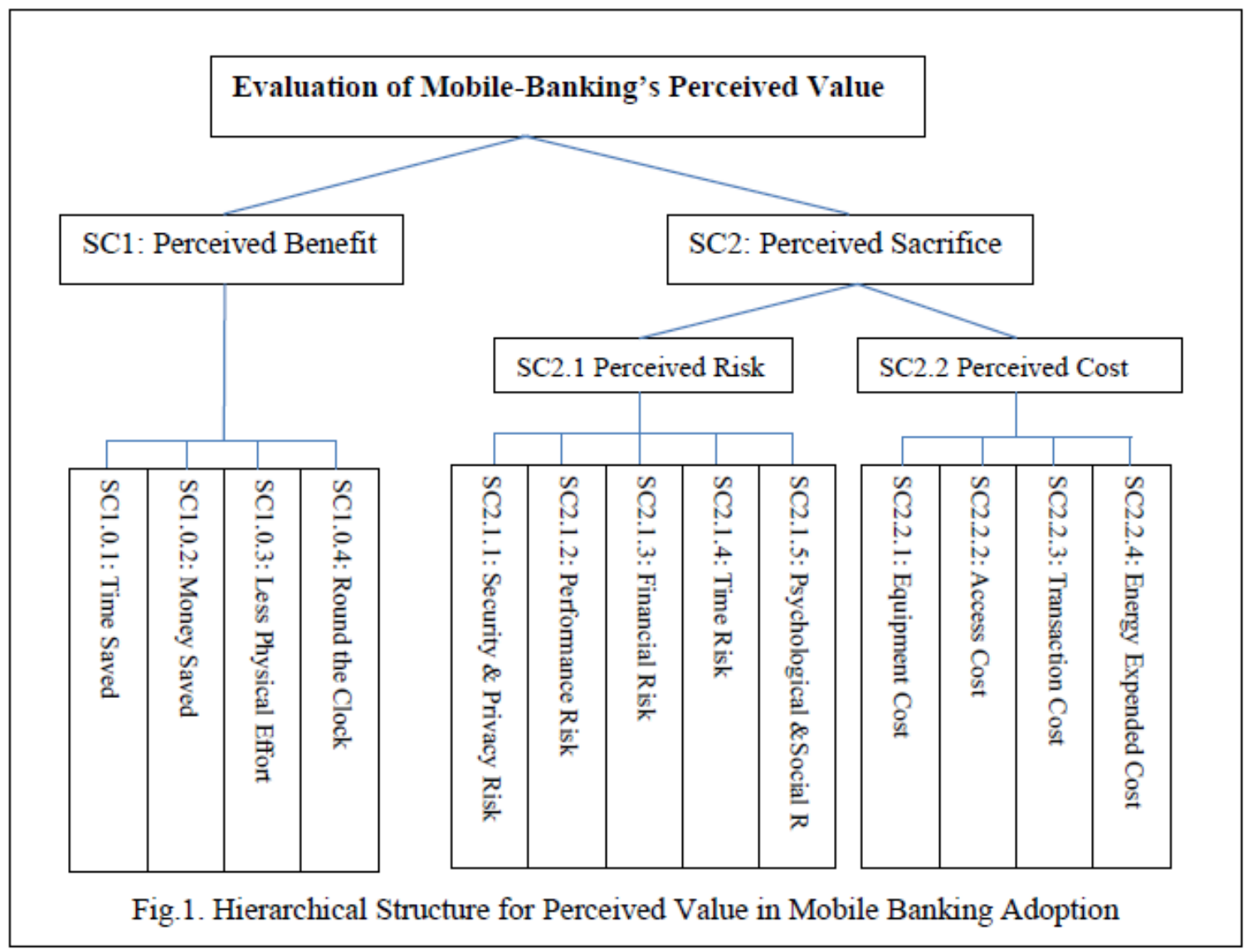

As soon as the decision hierarchy for the problem is made, the weights of the criteria and subcriteria to be used in assessment process are calculated by using AHP method (tables 3, 4, 5, 6, 7). At this stage, every survey participants has been assigned a task to form individual pairwise comparison matrix by using the Saaty's 1-9 scale (Table1).

\begin{tabular}{|l|l|l|}
\hline \multicolumn{3}{|c|}{ Table 3. Reporting of Perceived Value factors } \\
\hline & $\begin{array}{l}\text { Perceived } \\
\text { Benefit }\end{array}$ & Perceived Sacrifice \\
\hline $\begin{array}{l}\text { Perceived } \\
\text { Benefit }\end{array}$ & 1 & 5.00 \\
\hline $\begin{array}{c}\text { Perceived } \\
\text { Sacrifice }\end{array}$ & 0.20 & 1 \\
\hline
\end{tabular}

\begin{tabular}{|l|l|l|}
\hline \multicolumn{3}{|c|}{ Table 4. Reporting of Perceived Sacrifice factors } \\
\hline & $\begin{array}{l}\text { Perceived } \\
\text { Risk }\end{array}$ & $\begin{array}{l}\text { Perceived } \\
\text { Cost }\end{array}$ \\
\hline $\begin{array}{l}\text { Perceived } \\
\text { Risk }\end{array}$ & 1 & 2.00 \\
\hline $\begin{array}{l}\text { Perceived } \\
\text { Cost }\end{array}$ & 0.50 & 1 \\
\hline
\end{tabular}


International Journal of Data Mining \& Knowledge Management Process (IJDKP) Vol.6, No.3, May 2016

\begin{tabular}{|l|l|l|l|l|}
\hline \multicolumn{5}{|c|}{ Table 5. Altemative Factors of Perceived Benefit } \\
\hline & $\begin{array}{l}\text { Time } \\
\text { Saved }\end{array}$ & $\begin{array}{l}\text { Money } \\
\text { Saved }\end{array}$ & $\begin{array}{l}\text { Less Phys. } \\
\text { Effort }\end{array}$ & $\begin{array}{l}\text { Round } \\
\text { Clock }\end{array}$ \\
\hline $\begin{array}{l}\text { Time } \\
\text { saved }\end{array}$ & 1 & 0.33 & 2.00 & 1.00 \\
\hline $\begin{array}{l}\text { Money } \\
\text { Saved }\end{array}$ & 3.00 & 1 & 3.00 & 2.00 \\
\hline $\begin{array}{l}\text { Less Phys. } \\
\text { Eff }\end{array}$ & 0.50 & 0.33 & 1 & 1.00 \\
\hline $\begin{array}{l}\text { Round } \\
\text { Clock }\end{array}$ & 1.00 & 0.50 & 1.00 & 1 \\
\hline
\end{tabular}

\begin{tabular}{|l|l|l|l|l|}
\hline \multicolumn{5}{|c|}{ Table 6.Altemative Factors of Perceived Cost } \\
\hline & EC & AC & TC & EEC \\
\hline EC & 1 & 0.33 & 0.25 & 2.00 \\
\hline AC & 3.00 & 1 & 0.50 & 4.00 \\
\hline TC & 4.00 & 2.00 & 1 & 5.00 \\
\hline EEC & 0.50 & 0.25 & 0.20 & 1 \\
\hline EC: Equipment Cost; AC: Access Cost \\
TC: Transaction Cost; \\
EEC: Energy Expended Cost \\
\hline
\end{tabular}

\begin{tabular}{|l|l|l|l|l|l|}
\hline Table7.Altemative Factors of Perceived Risk & $\begin{array}{l}\text { Security and } \\
\text { Privacy }\end{array}$ & $\begin{array}{l}\text { Performance } \\
\text { Risk }\end{array}$ & $\begin{array}{l}\text { Financial } \\
\text { Risk }\end{array}$ & $\begin{array}{l}\text { Time } \\
\text { Risk }\end{array}$ & $\begin{array}{l}\text { Psychological } \\
\text { \&Social Risk }\end{array}$ \\
\hline Security and Privacy Risk & 1 & 4.00 & 0.50 & 3.00 & 3.00 \\
\hline Performance Risk & 0.25 & 1 & 0.20 & 2.00 & 1.00 \\
\hline Financial Risk & 2.00 & 5.00 & 1 & 3.00 & 2.00 \\
\hline Time Risk & 0.33 & 0.50 & 0.33 & 1 & 0.33 \\
\hline Psychological \&Social Risk & 0.33 & 1.00 & 0.50 & 3.00 & 1 \\
\hline
\end{tabular}

\begin{tabular}{|c|c|c|c|c|c|c|c|c|}
\hline $\begin{array}{l}\text { Level1: } \\
\text { Criteria }\end{array}$ & $\begin{array}{l}\text { A: } \\
\text { Initial } \\
\text { Weight }\end{array}$ & $\begin{array}{l}\text { Level2: } \\
\text { Sub- } \\
\text { criteria }\end{array}$ & $\begin{array}{l}\text { B:Intial } \\
\text { Weight } \\
\text { of Sub- } \\
\text { criteria } \\
\text { (level2) }\end{array}$ & $\begin{array}{l}C=A^{*} B \\
\text { Global } \\
\text { Weights: } \\
\text { Streamed } \\
\text { Weights of } \\
\text { sub-criteria }\end{array}$ & $\begin{array}{l}\text { Level3: } \\
\text { Alternatives }\end{array}$ & $\begin{array}{l}\text { D:Local } \\
\text { Weights: } \\
\text { Initial } \\
\text { Weights of } \\
\text { Alternatives }\end{array}$ & $\begin{array}{l}\mathrm{E}=\mathrm{C}^{*} \mathrm{D} \\
\text { Global } \\
\text { Weight: } \\
\text { normalized } \\
\text { weights of } \\
\text { alternatives }\end{array}$ & $\begin{array}{l}\text { Consistency } \\
\text { Ratio, } \\
\lambda_{\max }\end{array}$ \\
\hline $\begin{array}{l}\text { C1: } \\
\text { (Perceived } \\
\text { Benefit) }\end{array}$ & $83.3 \%$ & SC1.1 & - & $83.3 \%$ & $\begin{array}{l}\text { SC1.1.1 } \\
\text { SC1.1.2 } \\
\text { SC1.1.3 } \\
\text { SC1.1.4 }\end{array}$ & $\begin{array}{l}20.5 \% \\
46.2 \% \\
14.4 \% \\
18.8 \%\end{array}$ & $\begin{array}{l}8.53 \%(4) \\
19.22 \%(2) \\
5.99 \%(7) \\
7.82 \%(6)\end{array}$ & $\begin{array}{l}\mathrm{CR}=3.0 \% \\
\lambda_{\max } \\
=4.081\end{array}$ \\
\hline \multirow[t]{2}{*}{$\begin{array}{l}\mathrm{C} 2: \\
\text { (Perceived } \\
\text { Sacrifice) }\end{array}$} & \multirow[t]{2}{*}{$16.7 \%$} & \begin{tabular}{|l|}
$\mathrm{SC} 2.1$ \\
(Perceived \\
Risk)
\end{tabular} & $66.7 \%$ & $11.138 \%$ & $\begin{array}{l}\mathrm{SC} 2.1 .1 \\
\mathrm{SC} 2.1 .2 \\
\mathrm{SC} 2.1 .3 \\
\mathrm{SC} 2.1 .4 \\
\mathrm{SC} 2.1 .5\end{array}$ & $\begin{array}{l}29.6 \% \\
10.4 \% \\
38.0 \% \\
7.6 \% \\
14.5 \%\end{array}$ & $\begin{array}{l}16.46 \%(3) \\
5.78 \%(8) \\
21.13 \%(1) \\
4.23 \%(9) \\
8.06 \%(5)\end{array}$ & $\begin{array}{l}\mathrm{CR}=6.4 \% \\
\lambda_{\max } \\
=5.288\end{array}$ \\
\hline & & $\begin{array}{l}\text { SC2.2: } \\
\text { (Perceived } \\
\text { Cost) }\end{array}$ & $33.3 \%$ & $5.561 \%$ & $\begin{array}{l}\mathrm{SC} 2.2 .1 \\
\mathrm{SC} 2.2 .2 \\
\mathrm{SC} 2.2 .3 \\
\mathrm{SC} 2.2 .4\end{array}$ & $\begin{array}{l}12.5 \% \\
30.6 \% \\
49.2 \% \\
7.8 \%\end{array}$ & $\begin{array}{l}0.35 \%(12) \\
0.85 \%(11) \\
1.37 \%(10) \\
0.22 \%(13)\end{array}$ & $\begin{array}{l}\mathrm{CR}=1.8 \% \\
\lambda_{\max } \\
=4.048\end{array}$ \\
\hline
\end{tabular}




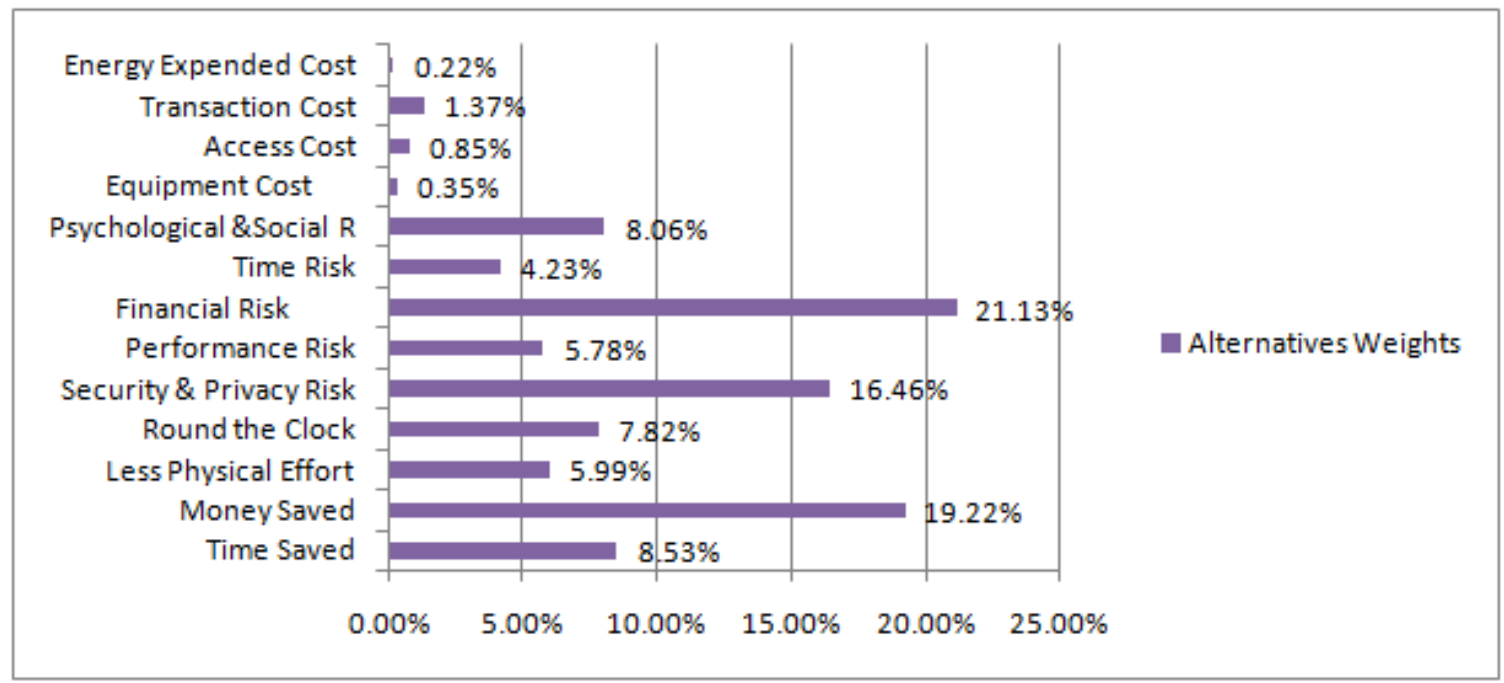

Fig.2. Final sub-criteria 2 (Alternatives) weight obtained via AHP

\section{RESULTS ANALYSIS AND DISCUSSIONS}

This study pulls out the factors that seem to influence the value perceived in m-banking adoption. The elements or factors weights in Table. 8 and fig. 2 refer to the importance that the participants give to the associated factors. As a result, the higher the weight, the greater is the impact. Consequently, the more the attention to the promotional priorities for mobile banking service is needed. The following subsections clarify the interactions among different weights in the criteria, sub-criteria and alternatives.

Firstly, the level 1 (Criteria) indicates that, perceived benefit $(83.3 \%)$ is a lot more significant than perceived sacrifice (16.7\%). This result shows that the value-added services in mobile banking is affecting positively mobile banking customer's demands in terms of alternatives identified. Therefore, to satisfy the request of consumer's benefits, mobile bank service operators should definitely incorporate the resources that may offer more opportunity to enjoy saving their money and time, with less physical effort at any time and everywhere compared to others selfservice technology put in place or even the traditional banking service in order to provide ample and rich value-added services.

Secondly, the level 2 shows that, in the sub-criteria category, it is only perceived sacrifice criteria that have sub-criteria i.e. perceived risk and perceived sacrifice.

Thirdly, the level 3 indicates one part, the alternative factors within the perceived benefit having the highest rank respectively: Money Saved (19.22\%) as the utmost higher, times saved $(8.53 \%)$, round the clock $(7.82 \%)$, less physical effort $(5.99 \%)$. Money and time saved alternatives reveal how it is faster and convenient for consumers to m-banking or online banking than going to a bank branch in person saving cost and in travel time, and been satisfy without time limitation.

Regarding to perceived risk factor, the findings show that, users were more concerned with their financial risk $(21.13 \%)$, followed by security\& privacy risk $(16.46 \%)$, less more on psychological $\&$ social risk $(8.06 \%)$ and less emphasis was placed on performance risk $(5.78 \%)$ followed by time risk $(4.23 \%)$. The finding can be used to explain the facts that, the consumers always care for 
International Journal of Data Mining \& Knowledge Management Process (IJDKP) Vol.6, No.3, May 2016

their money matters and the security issues involve in the use of mobile for the bank transactions. While financial risk is defined as the potential for monetary loss due to transaction error or bank account misuse, the security \& privacy are the possible loss due to a hacker or fraud compromising the security of an M-Banking user and Potential loss of control over personal information.

Banks operating m-banking therefore should be able to guarantee their consumers that the transfer of data has security mechanisms and confidentiality.

Concerning psychological \& social risk aspect, the m-banking users' attentions are somehow focused on the disappointment, shame or even frustration if personal information is released. At the same time, social risk may denote the possibility that using $\mathrm{m}$ - banking might lead to disapproval of a person's family, friends and colleagues. As we believe that individuals have the subjective norm that they are concerned about the opinions of their family, friends and colleagues vis-à-vis to their own actions. Therefore these externals factors may hinder the consumer acceptance or unwillingness using m-banking even a simple smart-phone.

The performance risk and the time risk was not so important to the customers, perhaps, they think that the online banking could also offers almost the same advantage.

In relation to the cost that has to be incurred in terms of sacrifice by using m-banking, transaction cost $(1.37 \%)$ followed respectively by access cost $(0.85 \%)$, equipment cost $(0.35 \%)$ and lastly by energy expended $\operatorname{cost}(0.22 \%)$. This result indicates how consumers were reasonably worried about the fees charge by its m-banking operators. They might find the cost of the transaction higher for them, and accessing just their financial bank information may also demand a fee to pay. In contrast, less emphasis were put on equipment cost and energy cost. This is because; most of the potential m-banking users have personal smart-phones or are using them already, not necessary for the purpose of m-banking. Hence think of buying a new phones are not so important part of their priorities.

Overall opinion of all the sub-criteria items point toward the financial risk $(21.13 \%)$ as the most importance factor from the consumer's point of view follow in order by money saved (19.22\%), security \& privacy risk $(16.46 \%)$. One can argue that users in m-banking want to insure if the service the bank is offering can reduce or even eliminate any type of risk related to their finances and keep their money saved while the system can also convince them about safety and personal information secrecy.

We consider that the major motive for customers to embrace m-banking is to access mobile banking services, which implies that financial risk, money saved, security \& privacy of their personal information, are called for an extra attention related to their mobile payments. Thus comprehensive risk reducing system particularly financial, security mechanisms, and inexpensive transaction and access cost can improve consumer perception of reliability, and consequently leading to the increased adoption of mobile banking. Indeed, if mobile banking service operators aspire to really uphold mobile banking services in this consumer-oriented era, there is need to better allocate the sufficient resources and make amendments to the areas where consumers believe such improvements are vital and so relevant for the future. 


\section{CONCLUSIONS AND LIMITATIONS}

Due to the series of foremost changes taking place in the financial services institutions, combined with the growth in the Information Technology, it is crucial to develop strategic plans that can maintain both existing and potential customers. In order to build a long term relationship with its consumers, and well benefit from the customer base loyal to the firm [62], management-oriented policies toward the perceived value by the customer remain an imperative issue.

As a result, the principal source of competitive advantage is to create an opportunity that gives the customers with a perceived value higher than that of the competitors, which leads to gaining a competitive advantage in that marketplace.

Having that logic in mind, this research has been grounded on the unidimensional approach which considered perceived value as the tradeoff between perceived benefit and perceived sacrifice and distinguishes some influential factors quite different from the traditional unidimensional construct. This study identified some key factors underlying perceived value in the decision to implement or adopt m-banking by Togolese customers. These factors consist of time saved, money saved, less physical effort, round clock, security and privacy risk, performance risk, financial risk, time risk, psychological \&social risk, equipment cost, access cost, transaction cost, energy expended cost. Hence, the hierarchical structure made in this study used these above factors that both literature reviews and experts confirmed to be the most important factors in the selection and adoption of a mobile banking service. The outcome, based on the final weighting of the mentioned factors, highlight the importance attributed to each factor. Unlike the previous scholar on the m-banking adoption investigations, this proposed approach of methodology used makes this research so distinctive because it recognizes that the best allocation of resources or limited resource to build an effective business model is a multi-criteria decisionmaking (MCDM) problem. Although AHP is not the only best approach for complex decision making problems-solving, it is acknowledged as an instrument to provide rational solution where the prioritizing issues arises. The identified factors i.e. criteria, sub-criteria and alternatives have been used by AHP to validate the most significant elements contributing to the adoption of $\mathrm{m}$ banking. Results indicate that, among the criteria, perceived benefit $(83.3 \%)$ have placed on first behind perceived sacrifice $(16.7 \%)$. And also prioritizing sub-criteria of perceived sacrifice, the result appears that the perceived risk $(66.7 \%)$ dimensions possess the higher priority compared with perceived cost $(33.3 \%)$. Lastly among the alternatives, financial risk $(21.13 \%)$, money saved $(19.22 \%)$, security \& privacy risk have been revealed respectively as highest among other alternatives. According to findings, it can be suggested that the adoption or the growth of the mbanking depends highly on the reducing monetary or financial issues from the consumer's perspectives and making sure that the system security is reliable enough to protect personal and privacy information. In this sense, and in view of the outcomes achieved, it is imperative to highpoint that the most important elements of the value perceived by the participants in the banking sector have to be taking with diligent. To sum up, these three implications which are brought into being will aid mobile banking providers to build more robust business models. The more these companies appreciate the degree of importance of any factor at a point; the more the aforementioned factors can help them to develop a supplementary competitive model, resulting in lower costs follow the greater efficiency.

A number of questions remain to be addressed. The shortcoming of this research rely mostly on the fact that the participants do not represent the entire population of Togo, the primary data 
International Journal of Data Mining \& Knowledge Management Process (IJDKP) Vol.6, No.3, May 2016

collected was only limited to the capital Lomé and amongst a few university students. Moreover the population used in this study is not randomly chosen. In this regard, our finding is just the opinion of the respondents and can hardly be generalizable and claims as valid for the whole Population. Future research may be concentrated using the representative population of Togo with AHP Method combined with cluster analysis.

Furthermore, there is an appeal to search for additional variables that can increase our ability to more accurately predict and evaluate consumer's intention to use or adopt m-banking. A suggestion for Fuzzy AHP will also be welcomed, as it has been proved to truly reflect human cognitive processes with precision.

\section{REFERENCES}

[1] Safeena, R., Date, H., Kammani, A., Hundewale, N., (2012). "Technology adoption and Indian consumers: study on mobile banking”. Int. J. Comput. Theory Eng. 4 (6), 1020-1024)

[2] Dineshwar, R., Steven, M., (2013) "An investigation on mobile banking adoption and usage: a case study of Mauritius". In: Proceedings of the 3rd Asia-Pacific Business Research Conference, Kuala Lumpur, Malaysia).

[3] Dwivedi, Y.K. and Irani, Z. (2009) "Understanding the adopters and non-adopters of broadband", Communications of the ACM, Vol. 52 No. 1, pp. 122-125.)

[4] Levesque, T.J. and McDongall, G.H. (1996) "Customer Dissatisfaction: The Relationship between Types of Problems and Customer Response". Canadian Journal of Administrative Sciences, 13, 264276.

[5] Holmes, G. (2011). Card and mobile payment opportunities: A framework to consider potential winners and losers and a snapshot of the future payments landscape in Africa. Journal of Payments Strategy and Systems, 5(2), 134-142

[6] Bold, C., Porteous, D. and Rotman, S. (2012). Social cash transfers and financial inclusion: Evidence from four countries. Consultative Group for Assisting the Poor (CGAP), February, 1-20.

[7] ALome (2015)“ Faible taux du «Mobile Banking» au Togo”, Source: Financial afrik, 22 juillet (French language)

[8] Gbongli Komlan (2016), “Integrating AHP-TOPSIS Approach on Prioritizing Self-Service Technology (SST) Decision Making in Financial Institution (TOGO)" British Journal of Mathematics \& Computer Science 16(3): 1-22

[9] Pearce, J.A.II. \& Robinson, R.B. Jr. (1989). Management. N.Y: Random House inc.

[10] Rogers, E. M. (2003). Diffusion of innovations (5th Ed.). New York: Free Press

[11] Featherman, M.S. and Pavlou, P.A. (2003), "Predicting e-services adoption: a perceived risk facets perspective", International Journal of Human-Computer Studies, 59 (4): 451-74.

[12] Gefen, D., Rao, V., \& Tractinsky, N. (2003). Conceptualization of trust, risk and their relationship in electronic commerce: The need for clarifications. Proceedings of the 36th Hawaii International Conference on IS 
International Journal of Data Mining \& Knowledge Management Process (IJDKP) Vol.6, No.3, May 2016

[13] Layla Alsheikh1 and Jamil Bojei 21 Putra Business School, University Putra Malaysia, Malaysia (Determinants Affecting Customer's Intention to Adopt Mobile Banking in Saudi Arabia , International Arab Journal of e-Technology, Vol. 3, No. 4, June 2014 :210-219,

[14] Cronin, J. Jr, Brady, M. and Hult, T. (2000), "Assessing the effects of quality, value, and customer satisfaction on consumer behavioral intentions in service environments", Journal of Retailing, 76 (2):193-218

[15] Pin Luarn , Hsin-Hui Lin,(2005) "Toward an understanding of the behavioral intention to use mobile banking" Computers in Human Behavior 21: 873-891

[16] Ulun Akturan, Nuray Tezcan, (2012) "Mobile banking adoption of the youth market: Perceptions and intentions", Marketing Intelligence \& Planning, 30(4):444 - 459

[17] Al-Jabri, Ibrahim M. and Sohail, M. Sadiq, (2012), "Mobile Banking Adoption: Application of Diffusion of Innovation Theory. Journal of Electronic Commerce Research, 13(4): 379-391

[18] Saaty T L (1980) “The Analytic Hierarchy Process”, McGraw Hill International.

[19] Hsiu-Fen Lin (2013), "Determining the relative importance of mobile banking quality factors" Computer Standards \& Interfaces 35:195-204

[20] Komlan Gbongli, Yi Peng, Owusu Ackah, (2016) "Selection and ranking of perceived risk associated with mobile banking in West Africa: An AHP Approach from customers' perspective", International Journal of Scientific \& Engineering Research, 7(1):80-86

[21] H. W. Kim, H. C. Chan, S. and Gupta, (2007), "Value-based Adoption of Mobile Internet: An Empirical Investigation,” Decision Support System, 43:111-126

[22] Teas, K. and Agarwal, S. (2000), "The effects of extrinsic product cues on consumers' perceptions of quality, sacrifice and value", Journal of the Academy of Marketing Science, 28(2): 278-290

[23] Bettman, J., Luce, M. and Payne, J. (1998), "Constructive consumer choice process", Journal of Consumer Research, 25(3):187-217

[24] Zeithaml, V. A. (1988), "Consumer perceptions of price, quality, and value: A Means-End model and synthesis of evidence", Journal of Marketing, 52(3):2-22)

[25] Bankole, F. O., Bankole, O. O., Brown, I. (2011), "Mobile Banking Adoption in Nigeria", The Electronic Journal of Information Systems in Developing Countries (EJISDC), 47(2):1- 23

[26] Ruiz, D. M., Gremler, D. D., Washburn, J. H., \& Carrión, G. C. (2010), "Reframing customer value in a service-based paradigm: An evaluation of a formative measure in a multi-industry, cross-cultural context". In V. E. Vinzi, W. W. Chin, J. Henseler \& H. Wang (Eds.), Handbook of Partial Least Squares: Concepts, Methods and Applications: Springer.

[27] Chi, T., \& Kilduff, P. P. D., (2011), "Understanding consumer perceived value of casual sportswear: An empirical study", Journal of Retailing and Consumer Services, 18(5): 422-429

[28] Dodds, W. B., \& Monroe, K. B. (1985), "The effect of brand and price information on subjective product evaluations", Advances in Consumer Research, 12(1):85-90 
International Journal of Data Mining \& Knowledge Management Process (IJDKP) Vol.6, No.3, May 2016

[29] Zeithaml, V. A. (1988), "Consumer perceptions of price, quality, and value: A Means-End model and synthesis of evidence". Journal of Marketing, 52(3), 2-22

[30] Sweeney, J. C., \& Soutar, G. N. (2001), "Consumer perceived value: The development of a multiple item scale" Journal of Retailing, 77(2), 203- 220

[31] Mattson, J. (1991), Better Business by the ABC of Values, Studentliteratur, Lund

[32] Sheth, J.N., Newman, B.I. and Gross, B.L. (1991a), "Why we buy what we buy: a theory of consumption values", Journal of Business Research, 22: 159-70

[33] Sheth, J.N., Newman, B.I. and Gross, B.L. (1991b), "Consumption Values and Market Choices: Theory and Applications", Southwestern Publications, Amarillo, TX

[34] Lee MC., (2008), Predicting behavioral intention to use online banking. In: Proceedings of the 19th international conference on information management. Taiwan

[35] Shun Yin Lam, Venkatesh Shankar, M. Krishna Erramilli, Bvsan Murthy, (2004) "Customer value, satisfaction, loyalty, and switching costs: an illustration from a business-to-business service context" J Acad Mark Sci, 32: 293-311

[36] Chien-Hsin Lin, Peter J. Sher, Hsin-Yu Shih, (2005) "Past progress and future directions in conceptualizing customer perceived value" Int J Serv Ind Manag, 16 (4):318-336

[37] Yonggui Wang, Hing Po Lo, Reyong Chi, Yongheng Yang,(2004), "An integrated framework for customer value and customer-relationship-management performance: a customer-based perspective from China” Manag Serv Qual, 14 (2/3):169-182.

[38] Luo, X., Li, H., Zhang, J., \& Shim, J.P. (2010). "Examining multi-dimensional trust and multi-faceted risk in initial acceptance of emerging technologies: An empirical study of mobile banking services", Decision Support System, 49(2): 222-234

[39] Bauer, R., (1967), Consumer behavior as risk taking. In: Cox, D. (Ed.), Risk Taking and Information Handling in Consumer Behavior. Harvard University Press, Cambridge, MA.

[40] Peter, J., Ryan, M., (1976), "An investigation of perceived risk at the brand level", Journal of Marketing Research 13, 184-188

[41] Lin W-B., (2008), "Investigation on the model of consumers' perceived risk - integrated viewpoint". Expert Syst Appl, 34(1):977-88

[42] Cunningham SM. (1967), The major dimensions of perceived risk. In: Cox DF, editor. Risk taking and information handling in consumer behaviour. Boston: Harvard University Press; 1967

[43] Jacoby J, Kaplan L. B, (1972), the components of perceived risk. In: Venkatesan M, editor. Advances in consumer research. Chicago: Association for Consumer Research

[44] Kaplan LB, Szybille GJ, et al., (1974), Components of perceived risk in product purchase: a cross validation. J Appl Psychol ;59(3):278-91

[45] Roselius T, (1971), “Consumer rankings of risk reduction methods”. J Market ;35(1): 56-61 
International Journal of Data Mining \& Knowledge Management Process (IJDKP) Vol.6, No.3, May 2016

[46] Saaty, T. L. (1977). A scaling method for priorities in hierarchical structures. Journal of Mathematical Psychology, 15(3): 234-281

[47] Corner, J. L., Buchanan, J., and Henig, M. (2001). ” Dynamic decision problem structuring”. Journal of Multi-Criteria Decision Analysis, 10:129-141

[48] Liberatore, M.J., and Nydick, R.L., (1997), "Group Decision Making In Higher Education Using The Analytic Hierarchy Process” Research In Higher Education, 38(5): 593-614

[49] Yoo, K.E.,and Choi, Y.C.,(2006), "Analytic Hierarchy Process Approach For Identifying Relative Importance Of Factors To Improve Passenger Security Checks At Airports", Journal of Air Transport Management 12, 135-142

[50] Saaty, T.L. (2008) "Decision making with the analytic hierarchy process", Int. J. Services Sciences, 1(1): 83-98

[51] Dagdeviren, M., Yavuz, S., Kilinc, N., (2009), "Weapon selection using the AHP and TOPSIS methods under fuzzy environment" Expert Systems with Applications, 36: 8143-8151.

[52] Saaty, T. L., and Vargas Luis L., (2001). "Models, Methods, Concepts and Applications of the Analytic Hierarchy Process" International Series in Operations Research and Management Science, Kluwer Academic Publishers

[53] Lee, S., Kim, W., Kim, Y.M., Oh, K.J., (2012). "Using AHP to determine intangible priority factors for technology transfer adoption" Expert Systems with Applications, 39: 6388-6395

[54] Lee, S., Kim, W., Kim, Y.M., Oh, K.J., (2012) "Using AHP to determine intangible priority factors for technology transfer adoption”, Expert Systems with Applications, 39: 6388-6395

[55] Acze'1, J., \& Saaty, T. L. (1983). Procedures for synthesizing ratio judgements. Journal of Mathematical Psychology, 27(1): 93-102

[56] Yin, R.K., (1994), Case study research: design and methods, Sage Publications, USA

[57] Miles, M. B. and A. M. Huberman, (1994), Qualitative Data Analysis: A Source Book of New Methods, Newbury Park, CA: Sage

[58] Oke, A. and M. Gopalakrishnan, (2009), "Managing Disruptions in Supply Chains: A Case Study of a Retail Supply Chain", International Journal of Production Economics 118: 168-174

[59] Duke, J., \& Aulla-Hyde, R. (2002), "Identifying public preferences for land preservation using the analytic hierarchy process", Ecological Economics, 42(1-2), 131-145

[60] Shrestha, R., Alavalapati, J., \& Kalmbacher, R. (2004), "Exploring the potential silvopasture adaption in South-Central Florida: An application of SWOT-AHP based method". Agricultural Systems, 81(3): 185-199

[61] A.Dias Jr., P.G. Ioannou,(1996), "Company and project evaluation model for privately promoted infrastructure projects, J. Constr. Eng. Manag. 122 (1): 71-82

[62] Jacoby, J. and Chestnut, R.W. (1978), Brand Loyalty Measurement and Management, John Wiley \& Sons, New York, NY 


\section{AUTHORS}

Gbongli Komlan is a Togolese. He got his Graduate Diploma in Management Studies from the Institute of Commercial Management (ICM), Bournemouth (U$\mathrm{K}$ ); his Master's degree in Management Science and Engineering from School of Management and Economics (SME), University of Electronic Science and Technology of China (UESTC)

$\mathrm{He}$ is currently a $\mathrm{PhD}$ Scholar at SME, UESTC. His research interests cover Multi-Criteria Decision Making (MCDM), knowledge discover in data mining, M-Banking, Foreign Direct investment (FDI)

Dumor Koffi is from Togo and received his Master degree in Economics from University of Lome. He is currently a Master student majoring in Management Science and Engineering, School of Management and Economics (SME), University of Electronic Science and Technology of China (UESTC).

He is currently working on Foreign Direct Investment (FDI)
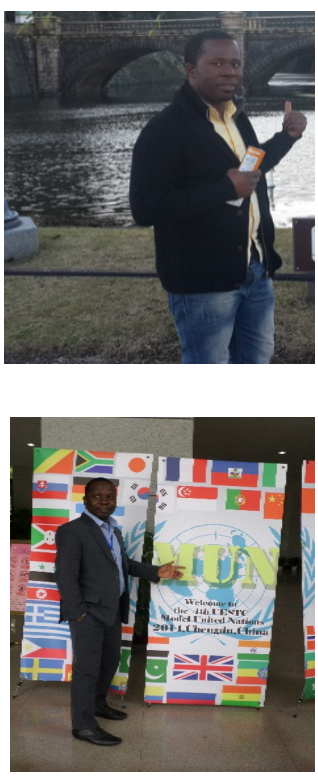

Kissi Mireku Kingsford is a Ghanaian with Post Graduate Diploma in Management Information Systems from Ghana Institute of Management and Public Administration (GIMPA), obtained MSc in Computer Science and Technology from University of Electronic Science and Technology of China (UESTC)

$\mathrm{He}$ is a $\mathrm{PhD}$ candidate in University of Electronic Science and Technology of China (UESTC), School of Information and Software Engineering. Researching on Big Data Privacy Preservation

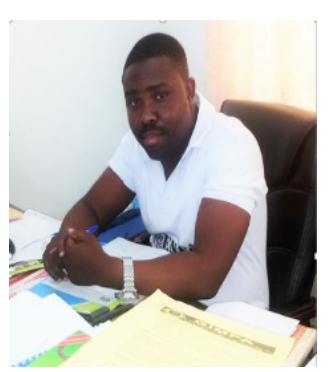

$\mathrm{He}$ is a Lecturer at Ghana Institute of Management and Public Administration and also the Ghana coordinator and examiner for IMIS-BCS, UK. 